症例

仙骨転移巣を切除した左副腎原発悪性褐色細胞腫の 1 例

藤田保健衛生大学内分泌・乳腺外科, 同 整形外科*

$\begin{array}{lllllll}\text { 神 } & \text { 保 } & \text { 慎 } & \text { 稲 垣 } & \text { 朝 } & \text { 小 林 尚 美 } \\ \text { 山 } & \text { 本 晴 大 } & \text { 岩 瀬 } & \text { 克 } & \text { 中 } & \text { 井 定 明* }\end{array}$

症例は54歳, 男性. 1994年 6 月, 腹痛を主訴にCT 検査を受け，左副腎腫瘤を指摘さ れた，高血圧症は認めないが，尿中カテコラミン（CA）は高值を示した。CT，MRIで は，左腎門部と大動脈に接し，腎動静脈の間に発育する境界明瞙で萁胞性変化を伴う最

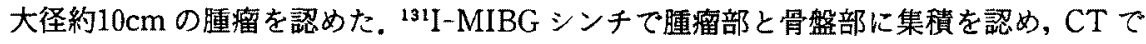
仙骨部に腫瘤を確認し，仙骨転移を伴う左副腎悪性褐色細胞腫（無症候性）と診断した。 10月, 左堅合併左副腎摘出術を施行. 腫搒は径 $10 \times 6 \times 4.5 \mathrm{~cm}$, 重量 $145 \mathrm{~g}$ で腎実質への 浸潤はなかった。組織学的には，分泌顆粒を持つ大小不同の好塩基性細胞の充実性增殖 を諗め，褐色細胞腫と診断された，術後，尿中 CA および代謝物は高值を持続し，4力 月後に仙骨部分切除術施行後には, 全ての尿中 CA は正常化した. 4 力月後歩行可能と なり退院. 術後 8 年経過した現在, 再発を認めない.

悪性褐色細胞腫の治療には手術, 化学療法, 動脈塞栓, ${ }^{131} \mathrm{I}-\mathrm{MIBG}$ 内照射などが挙げ られるが，いまだ確立されてはいない，われわれは仙骨部に単発性転移を伴った悪性副 腎褐色細胞腫に対して，原発および転移病変の二期的切除を施行し良好な結果を得た。

卖引用語：悪性褐色細胞腫, 仙骨転移, ${ }^{131} I-M I B G$ シンチグラフィー

はじめに

近年，画像診断の進歩，普及により副腎偶発腫瘍の 発見が飛躍的に增大している。これら副腎偶発腫晹の 手術適応としては，1)内分泌活性を有するもの，2) 悪性腫堭が疑われるもの，3）腫瘤よる症候を有する 大きな腫場などが挙げられている，副腎蹃質腫煌は比

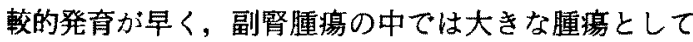
発見されることが多い.したがって，副腎偶発腫湯の 中で手術適応となるものとして褐色細胞腫は比較的多 いと言われている。

褐色細胞腫は本来発作性高血圧症を特徵とするが， 正常血圧（無症候性）のものも少なくない，また，本 症は $10 \%$ 病とも呼ばれ，多発性，両側性，副腎外，悪 性であることがそれぞれ10\%前後あるとされている。 さらに，内分泌腫瘍に共通した特徵ともいえるが，褐 色細胞腫の良悪性の鑑別診断は必ずしも容易ではな

2003年 6 月 13 日受付 2003 年 8 月 7 日採用 〈所属施設住所〉

テ470-1192 豊明市沓掛町田楽ケ寉 1 -98
い. したがって, 本症の猃療に当たっては以上の特徴 を踏まえた検索の上での適切な対処が必要となる，今 回われわれは，仙骨転移を伴う左副腎悪性褐色細胞腫 （無症候性）に対して原発および転移巣を二期的に切 除し，良好な経過が得られた 1 例を経験したので報告 する。

患者：54歳の男性.

主訴：腹痛。

既往歴：左眼失明, 左眼白内障. 高血圧症は認めな w.

家族歴：父親に楉尿病と高血圧を認めた。

現病歴：1994年 6 月, 腹痛を主訴に近医を受診した 際に腹部超音波および CT 検査を受け，左副腎部の腫 瘤を指摘され，同年 8 月に精査治療目的で当院紹介入 院となった。

入院時現症：血圧 $120 / 78 \mathrm{mmHg}$ ，脈拍 $72 /$ 分·整，身 長 $167 \mathrm{~cm}$, 体重 $66 \mathrm{~kg}$, 胸・腹部に異常なく，歩行障害， 排尿・排便障害も認めていなかった，入院時一般血液 検查でも異常を認めなかった。 


\section{表 1 検査所見}

\begin{tabular}{|c|c|c|}
\hline 検查項目 & $\begin{array}{c}\text { 治療前 } \\
(1994 / 9)\end{array}$ & $\begin{array}{c}\text { 治療後 } \\
(1997 / 2)\end{array}$ \\
\hline \multicolumn{3}{|l|}{ 1. カテコールアミン\&代謝物（尿中） } \\
\hline アドレナリン (3-15 $\mu \mathrm{g} / \mathrm{day})$ & $84.8 \uparrow$ & 5.7 \\
\hline ノルアドレナリン (26-121 $\mu \mathrm{g} /$ day $)$ & $236.5 \uparrow$ & 84.5 \\
\hline ドーパミン $(190-740 \mu \mathrm{g} /$ day $)$ & $5880.1 \uparrow$ & 547.9 \\
\hline VMA (1.3-5.1mg/day) & $40.1 \uparrow$ & 2.7 \\
\hline HVA $(1.5-6.6 \mathrm{mg} /$ day $)$ & $28.1 \uparrow$ & 2.8 \\
\hline 総メタネフリン $(0.12-0.49 \mathrm{mg} / \mathrm{day})$ & $13.24 \uparrow$ & 0.21 \\
\hline \multicolumn{3}{|l|}{ 2. カテコールアミン\&代謝物 (血中) } \\
\hline アドレナリン $(<100 \mathrm{pg} / \mathrm{ml})$ & 97 & \\
\hline ノルアドレナリン $(100-450 \mathrm{pg} / \mathrm{ml})$ & 348 & \\
\hline ドーパミン(<20pg/ml) & 23 & \\
\hline $\operatorname{VMA}(3-9 \mathrm{ng} / \mathrm{ml})$ & $48.6 \uparrow$ & \\
\hline HVA (4-15ng/ml) & $25.4 \uparrow$ & \\
\hline \multicolumn{3}{|l|}{ 3. 腫㾴マーカー } \\
\hline $\mathrm{CEA}(\leqq 2.5 \mathrm{ng} / \mathrm{ml})$ & 2.4 & \\
\hline $\mathrm{CA} 19-9(\leqq 37 \mathrm{U} / \mathrm{ml})$ & 8.6 & \\
\hline $\operatorname{NSE}(<10 \mathrm{ng} / \mathrm{ml})$ & 3.2 & \\
\hline
\end{tabular}

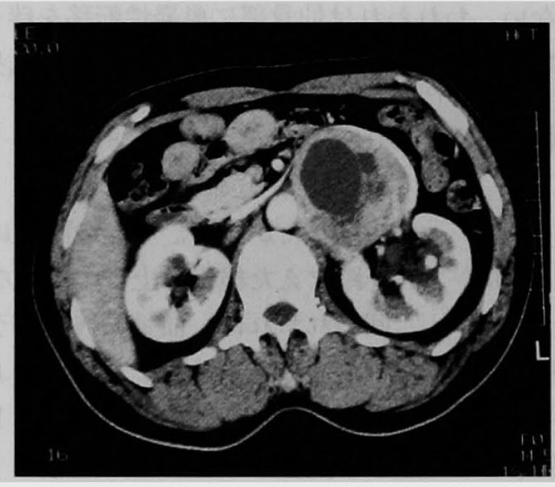

a

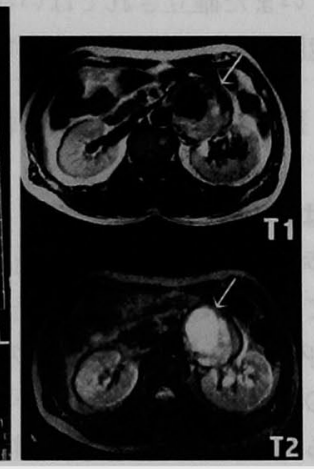

b

図 $1 \mathrm{a}$ 腹部 CT 検查：左腎上部に最大径約 $10 \mathrm{~cm}$, 辺縁ほほ整で内部 には低濃度領域を伴う腫瘦を認めた。腫癔は左腎動脈と左堅静脈の 間に発育し，動脈を背側に，静脈を腹側に圧排する。

b MRI 検査：形態的には CT と同様の所見を示した. 腫瘤の充 実性部分は T 1 強調像で僅かに高信号, T 2 強調像で高信号を示し, 不均一に描出されている. また, 中心部には多胞性の变胞性変化を伴 っている。

内分泌学的検査：血中カテコラミン (CA) は正常範 囲内であったが，CA 代謝物はVMA $48.6 \mathrm{ng} / \mathrm{ml}$, $\mathrm{HVA} 25.4 \mathrm{ng} / \mathrm{ml}$ と高值を示した。尿中 CA はアドレ

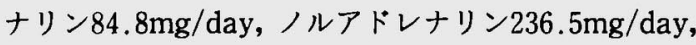
ドーパミン $5,880.1 \mathrm{mg} /$ day と高值を示し, 代謝物も尿
中総メタネフリン $13.24 \mathrm{mg} / \mathrm{day}, \mathrm{VMA} 40.1 \mathrm{mg} / \mathrm{day}$, HVA $28.1 \mathrm{mg} / \mathrm{day}$ と高値を示した（表 1 ）。なお，腫 瘍マーカーは正常であった。これらの結果から, 高血 圧は認められないが，機能性腫瘍である褐色細胞腫の 存在が示唆された。 


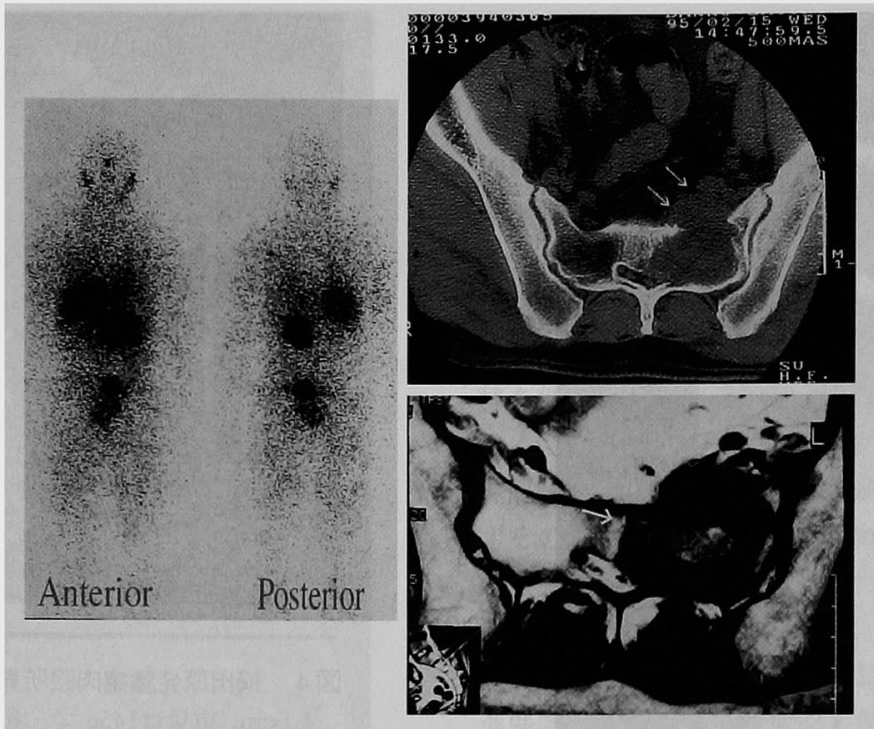

図 2 a ${ }^{131}$ I-MIBG シンチグラフィー : CT, MRI で認めた左副腎腫 瘍部に一致して強い集積を認めた.さらに仙骨左側にも強い集積が あり, 同部にもCA 産生病変の存在が疑われた。

b 仙骨部 CT：CTでは仙骨左側の骨は欠損し,腫瘍に置換され ている. 腫瘍の内部は僅かに低濃度を示し, 内側は脊柱管内へ突出 し, 馬尾神経は右方への偏位を示した. 病変は単発で下部仙骨は正常 であった.

c 仙骨部 MRI：MRI でも T 1 強調像で仙骨左上部に辺縁不整 な低信号領域を示し，内部に高信号領域を伴い, 前後に膨隆を認め た.

a $\mid \frac{b}{c}$

腹部 CT 検查：左腎上部に最大径約 $10 \mathrm{~cm}$ ，辺縁ほ 整で内部には低濃度領域を伴う腫瘤を認めた。腫瘤は 左腎をやや外側に圧排し, 腫瘤の内側は上腸間膜動脈 根部から腹部大動脈の左側壁に接する。腫瘤は左腎動 脈と左腎静脈の間に発育し, 動脈を背側に, 静脈を腹 側に圧排する.しかし, 明らかな周囲臟器への浸潤像 は認めず，大動脈周囲のリンパ節腫大もない，右副腎 および肝は正常であったが,両側の腎軎胞を認めた(図 1 a).

MRI 検查：形態的には CT と同様の所見を示した. 腫瘤の充実性部分は T 1 強調像で僅かに高信号, T 2 強調像で高信号を示し, 不均一に描出されている。 ま た, 中心部には多胞性の賈胞性変化を伴っている（図 $1 \mathrm{~b})$.ここれ CT および MRI 検查の所見はいずれも 褐色細胞腫の特徵に一致するもので左副腎褐色細胞腫 と診断された。しかし，形態的に明らかな悪性を示す 所見はなかった。

${ }^{131} I-M I B G$ シンチグラフィー：CT, MRI で認めた
左副腎腫黇部に一致して強い集積を認めた。さらに仙 骨左側にも強い集積があり, 同部にもCA 産生病変の 存在が疑われた。右副腎への集積は認めなかった（図 2 a).

褐色細胞腫の多発病変または悪性副腎褐色細胞腫の 仙骨転移が疑われ，仙骨部の CT, MRIによる精查を 進めた。

仙骨部 CT, MRI：CTでは仙骨左側の骨は欠損 し, 腫場に置換されている. 腫場の内部は僅かに低濃 度を示し, 内側は脊柱管内へ突出し, 馬尾神経は右方 への偏位を示した.腫瘤は腹側へも突出発育を認めた。 病変は単発で下部仙骨は正常であった (図 2 b). MRI でも T 1 強調像で仙骨左上部に辺緑不整な低信号領 域を示し, 内部に高信号領域を伴い, 前後に膨隆を認 めた(図 $2 \mathrm{c}$ ). 腪晹は明らかに仙骨に浸潤性に発育す るものであり，その形態的特徵は褐色細胞腫のそれに 一致するものであった。

以上, 内分泌学的検查と画像検查加ら仙骨転移を伴 


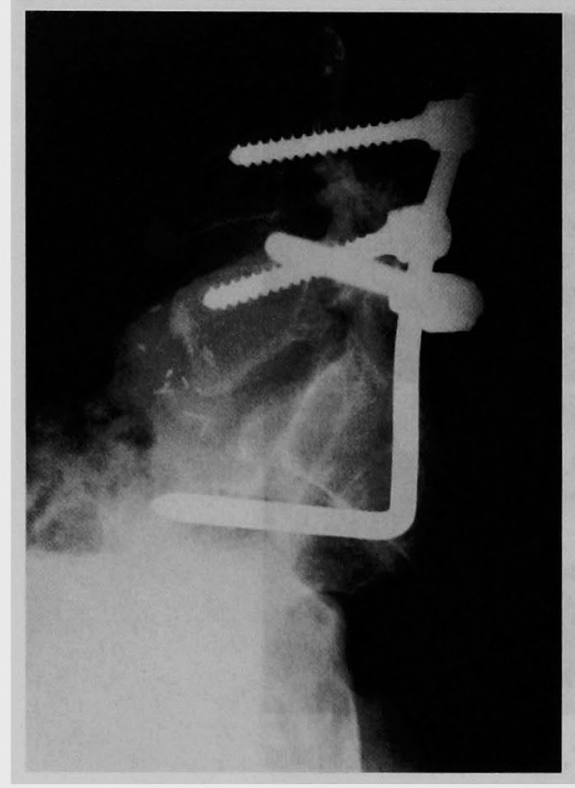

图 3 L 5 -S 1 後方固定術
つた左副腎原発悪性褐色細胞腫（無症候性）と診断し た.

入院精査期間中, 全く高血圧発作は認めなかったが, 尿中 CA 值からは CA 過剩分泌を示しており，治療と しては病変の全摘出が不可能としても, 腫瘍量を減少 させる必要があると考えられた。

手術所見：術前処置として $\alpha$-プロッカー(塩酸プラ ソシン $1.5 \mathrm{mg} / \mathrm{day})$ を約 1 力月間投与したが，血圧の 変動は認められなかったため, 最初に切除可能と判定 した原発病変である左副腎腫瘍の摘出術を施行した。

腫場は左副腎部に限局し, 周囲組織への明らかな浸 潤はなかった。しかし, 左堅動静脈と腹部大動脈に密 着し腎動静脈の温存は困難と判断し, 左副腎全摘およ び左腎合併切除術を行った。また，この時点で仙骨部 腫䬰は骨盤腔に膨隆した腫瘍として触知したが，周囲 蔵器への漫潤はなく, また腹腔内の他部位への腫瘍の 広がりは認めなかった。手術操作中は腫瘍への直接刺 激から, 血中 CA の著明な上昇とともに血圧上昇を呈 したが, そのコントロールは容易であり, 術後は直ち に血圧は正常化した。

仙骨部転移巣に対する治療としては, 腫瘍の占拠部 位と大きさから仙骨部分切除で摘出可能であり, それ によって術後機能障害も最小限に止められると判断 し, 外科治療を選択した. 自己血輸血の準備をしつつ,

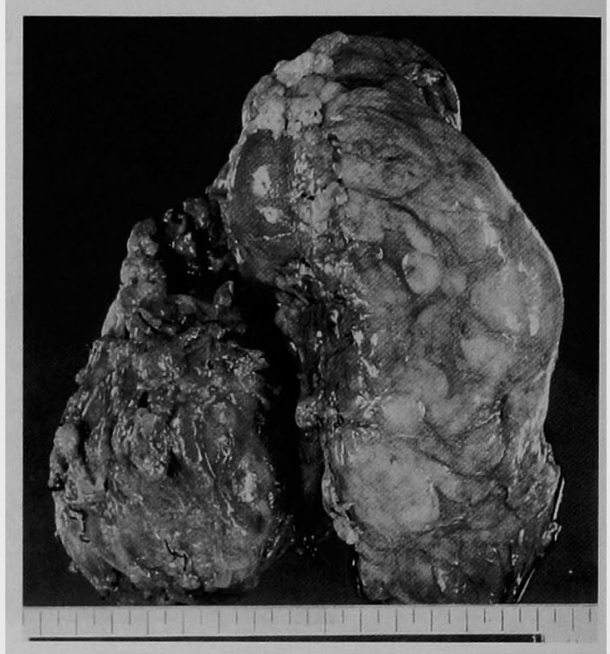

図 4 摘出原発腫瘍肉眼所見 : 大きさ $10 \times 6 \times$ $4.5 \mathrm{~cm}$, 重量は $145 \mathrm{~g} て$, 境界は明暸で隣接する 腎への明らかな浸潤は認めない. その割面所見 では中心壊死が認められ，その周囲は充実性で やや軟らかい腫瘍であった。

左副腎原発腫湯摘出後 4 力月経過した時点で, ${ }^{131} \mathrm{I}$ MIBG シンチグラフィーの再検を行い, 仙骨部以外に 集積がないことを確認し，仙骨転移巣の摘出術を施行 した.

術中出血の低隇と CA 放出の抑制を目的として, 手 術前日に内腸骨動脈塞栓術を行い, 仙骨部腫瘍は仙骨 部分切除術により摘出した。術中の CA 過剩分泌およ び血圧変動は認めなかった，仙骨切除部分が落ち着い た 2 週間後に二期的に L $5-\mathrm{S} 1$ 後方固定術を施行し た(図 3 ). 術後は軽度膀胱機能障害のみで直腸機能障 害はなく, 4 力月後には歩行も可能となり退院した.

病理組織所見：摘出された原発腫湟の肉眼所見は, 大きさ $10 \times 6 \times 4.5 \mathrm{~cm}$, 重量は $145 \mathrm{~g} て ゙ ，$ 境界は明瞭で 隣接する腎への明らかな浸潤は認めない. その割面所 見では中心壊死が認められ，その周囲は充実性でやや 軟らかい腫瘍であった（図4）.

組織学的には, 大小の腫瘍細胞の充実性増殖からな り，壊死が著明. 胞体は好塩基性で核は大小不同が目 立つが，核分裂像に乏しい，脈管侵襲はみられず悪性 を支持する所見はない(図 5 a )。一方，仙骨部腫瘍は 細胞質内に多数の細顆粒を有する腫瑒細胞が胞巣を形 成し，周囲に強い線維化を伴っている．基本的には副 腎腫瘍と共通の組織像て副腎腫崵の転移巣と診断した

(図 5 b). 


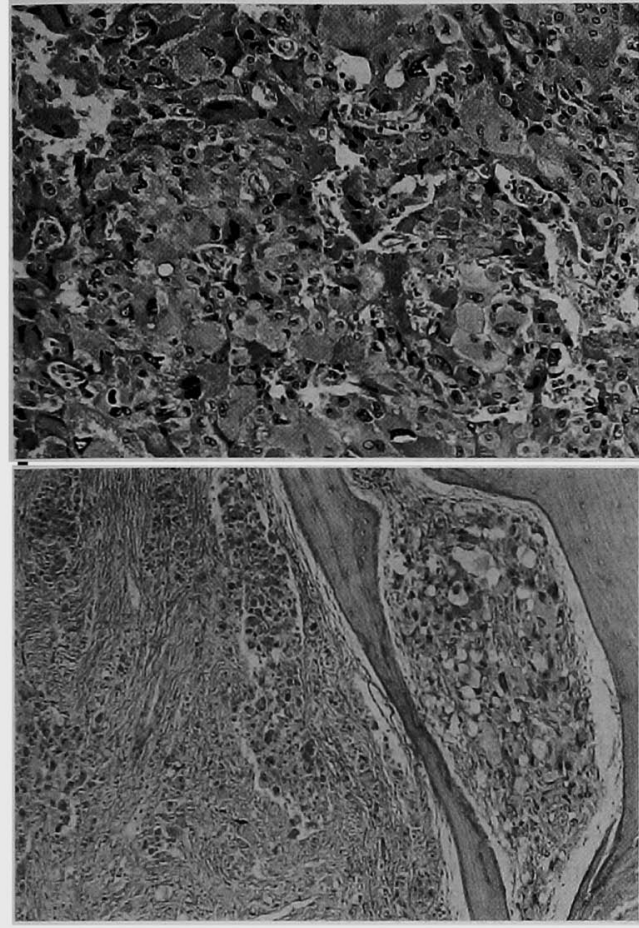

図 5 病理組織所見：a）大小の腫瘍細胞の充実性増 殖からなり，壊死が著明. 胞体は好塩基性で核は大 小不同が目立つが，核分裂像に乏しい，脈管侵俆は みられず悪性を支持する所見はない、b )仙骨部腫 湟は細胞質内に多数の細顆粒を有する腫瘍細胞が 胞巣を形成し，周囲に強い線維化を伴っている，基 本的には副腎腫瘍と共通の組織像で副腎腫瘍の転 移巣と診断した。

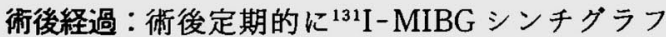
イーによる病変検索を行っているが, 術後 8 年の現在 まで異常集積は認めていない. 内分泌学的検査では, 原発巣摘除後, 転移巣摘除後と $\mathrm{CA}$ および CA 代謝物 の分泌量は段階的に減少し，その後は正常機能が維持 されている(表 1 )。現在は, 軽微な排尿障害の訴えは あるものの，血圧など再発を疑う所見はなく，就業を 含めて日常生活に全く支障のない良好な経過をたどっ ている.

\section{考 察}

悪性褐色細胞腫は褐色細胞腫全体の約 3〜14\%に存 在するといわれており ${ }^{1 ， そ の ~} 5$ 年生存率は約 $44 \%$ と 報告されている2゙. 組織学的に良性, 悪性を鑑別するこ とは困難であり, 骨(椎骨, 胁骨, 頭蓋骨, 骨盤など)， 肝，肺，リンパ節などの遠隔転移巣の存在により診断
されることが多いとされている゙).

発見の契機としては ${ }^{131}$ I-MIBG シンチグラフィー によるものが多いとされている，同検査は褐色細胞腫 の局在診断法の一つであるばかりでなく, 悪性腫晹の 可能性を念頭に入れ，転移栄の検索のために必ず施行 すべき検查法と考えられる4).

褐色細胞腫の治療としては, 外科的切除が唯一の最 も確実な方法である。しかし，本症例のように遠隔転 移を伴う悪性腫湯症例においては，画一的な治療法は なく,手術に換わる治療はいまた゚確立されてはいない. 遠隔転移を伴う悪性褐色細胞腫の治療に際しては，ま ずその目的として悪性腫颤に対する根治性の期待と内 分泌異常のコントロールの二つがある．しかし，患者 の予後と QOL を考慮した時，両者は密接に関連して おり，必ずしも別々のものとはならない．実際には， 進展度, 機能異常の程度など個々の腫演の特性を考慮 して最適なコントロール方法を選択することになる。

褐色細胞腫は高度に分化した内分泌腫垸として，そ の発育は比較的緩徐であり, 担癌状態でも長期生存が 期待できる.一方, 機能異常である発作性高血圧のコ ントロールが問題となり，それが不十分な場合には死 の危険を招くこととなる，機能異常の程度が低い場合 には，その危険はより小さくなり，より長期生存が期 待できることとなる。

遠隔転移を伴う症例では，病変は既に全身に及んで いることが多く，局所療法よりも全身療法を第一選択 とするのが合理的と考えられる．悪性褐色細胞腫に対 する化学療法として CVD(シクロホスファミド，ビン クリスチン，ダカルバジン) 療法 ${ }^{2) か ゙ ， ま た ~}{ }^{131} \mathrm{I}-\mathrm{MIBG}$ の大量内照射療法も腫場縮小と CA 分泌抑制の両効果 が知られている ${ }^{4) 51}$. 一方, 非観血的な転移巣の局所コ ントロールには，放射線外照射や血管塞栓療法なども 用いられる ${ }^{6) 7}$.これらの多くは反復治療を要するとと もに治療耐性や副作用の克服が大きな課題であり，131 I-MIBG 療法などはその経済性と保険医療上の観点か ら本邦では実施されていない，結局，非観血的治療は 血行動態の安定化と悪性例の手術前後の補助治療およ び手術不能例に限られることになる8).

以上の理由から，手術に酎えうる条件を持ち，QOL も考慮した上で相当期間の完全寛快が得られる可能性 があるならば，たとえ遠隔転移病変といえども局所療 法としての外科治療も積極的取り入れるべきと考えら れる。その際には，病変の存在部位によって整形外科 (骨転移)，胸部外科 (肺転移)，脳外科 (脳転移)，消 
化器外科 (肝転移) など他の診療科との連携が大切で ある。

本症例は臨床的にCA 過剩に伴う明らかな症候を持 たず，周術期管理が比較的容易であったこと，原発巣

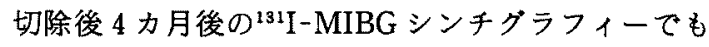
単発の転移巣しか認めなかったこと, 他に確実な治療 法がないことから，転移巣に対して整形外科の協力を 得て, 積極的な外科治療を選択し，良好な結果が得ら れた.

\section{文 献}

1) van Heerden JA, Sheps SG, Hamberger $B$, et al: Pheochromocytoma: Current status and changing trend. Surgery $91: 367-373,1982$

2) Averbuch SD, Steakley CS, Young RC, et al: Malignant pheochromocytoma : effective treatment with a combination of cyclophosphamide, vincristine, and dacarbazine. Ann Intern Med $109: 267-273,1988$

3）佐藤康幸, 舟橋啓臣, 今井常夫他：多発性骨転移 を伴う悪性褐色細胞臐症例に対する集学的治療。 日臨外医会誌 $54: 2911-2915 ， 1993$

4) Shapiro B:Imaging of catecholamine-secreting tumours: uses of MIBG in diagnosis and treatment. Bailieres Clin Endocrinol Metab Apri 7: 491-507, 1993

5）岡沢秀彦,遠藤啓吾,佐賀恒夫地：I-131Metaiodobenzylguanidine (MIBG)によるアイソトープ治 療が著効を示した恶性褐色細胞腫の1例。日本医 放会誌 $50: 286-294,1990$

6) Drasin $\mathrm{H}:$ Treatment of malignant pheochromyma. West J Med 128:106-111, 1978

7) 武田正之, 片桐明善, 金井利雄他：悪性褐色細胞 腫に対するCVD療法と選択的動脈塞栓療法によ る治療. 日泌会誌 $82 ： 826-829,1991$

8）湾辺瑛，浮村理，小島宗門他：褐色細胞腫の 非観血的治療. 内分泌外科 $11: 349-352,1994$

\title{
A CASE OF MALIGNANT LEFT ADRENAL PHEOCHROMOCYTOMA WITH METASTASIS TO THE SACRUM WHICH WAS SURGICALLY RESECTED
}

\author{
Shin JIMBO, Asako INAGAKI, Naomi KOBAYASHI, \\ Haruo YAMAMOTO, Katsumi IWASE and Sadaaki NAKAI* \\ Departments of Surgery and Orthopedics*, Fujita Health University School of Medicine
}

A 54-year-old man complaining of abdominal dull pain was referred to the hospital in June 1994 for further examination and treatment of a left adrenal tumor which was accidentally found by abdominal $\mathrm{CT}$ scan. Either hypertension or other abnormality was not shown although elevations of urinary catecholamine (CA), homovanillic acid, and vanillylmandelic acid were observed in laboratory examinations. Abdominal CT and magnetic resonance imaging scans revealed a well-defined tumor with cystic change inside, $10 \mathrm{~cm}$ in diameter in the left adrenal gland, and it grew between the renal vein front and renal artery behind. 131I-MIBG scintilation scan showed the uptake of 131I-MIBG not only in the tumor but also in the pelvis, and another tumor was confirmed in the sacrum by CT scan. A diagnosis of malignant adrenal pheochromocytoma with sacral metastasis was made based on these results, and surgical resection of the left adrenal gland and kidney, where the tumor could not be separated from renal vein or artery, was performed in October 1994. The elevations of both serum CA level and blood pressure were found in the midst of the surgery. The left adrenal tumor, which weighed $145 \mathrm{~g}$ and measured $10 \times$ $6 \times 4.5 \mathrm{~cm}$ in dimension, was histologically diagnosed as pheochromocytoma containing secreting granules. After the operation, urinary dopamine, HVA and VMA were still elevated. Since any other remained tumor except one in the sacrum was not found by 131I-MIBG scintilation scan which was performed 4 months after the surgery, a partial resection of the sacrum with the tumor was performed. After the 2nd surgery, urinary CA and its metabolites were all normalized, and 131I-MIBG scintilation scan showed no abnormal uptake. He could walk after the physical rehabilitation for 4 months, and left the hospital. Up to the present, no recurrences of the tumor are found by both laboratory examinations and 131I-MIBG scintilation scan.

Various therapies such as surgery, chemotherapy, arterial embolization, and external or internal radiotherapy using 1311-MIBG have been applied for metastatic lesions of malignant pheochromocytoma. We performed surgery on the present patient having a solitary metastatic lesion in the sacrum and could get a good clinical outcome. 